\title{
The Division of Community Property in Polygamy that Gives Legal Protection to the Wife
}

\author{
Heppy Hyma Puspytasari 1), Thohir Luth 2), Masruchin Ruba’i 3), Prija Djatmika 4)
}

1) Doctorate Candidate of Law Faculty, Brawijaya University, Malang, Indonesia, and Lecturer at the Study Programme of Civic Education of STKIP PGRI of Jombang, Indonesia

2) Professor on Islam Law of Law Faculty, Brawijaya University, Malang, Indonesia.

3) Postgraduate Program of Law Faculty, Brawijaya University, Malang, Indonesia.

4) Postgraduate Program of Law Faculty, Brawijaya University, Malang, Indonesia.

\begin{abstract}
:
Article 35 of the Marriage Law paragraph (1) states: Community property is property acquired by a couple during marriage. KHI article 94 states that community property in polygamous marriages is separated and independent. However, there is an opinion stating that article 94 is unfair for first wife, because they received the least portion among the other wives. In fact, first wife accompanied her husband for a longer time, and continued to accompany him in the next marriage. Of course it is considered unfair because first wife suffer the most, especially in terms of mental condition, because no woman is actually willing to share her husband with other women. The technical administration and technical guidelines for the Religious Courts are applied in the Religion Court based on the decision of the Chair of the Supreme Court of Republic of Indonesia Number: KMA/032/SK/IV/2006 concerning the implementation of "Book II Guidelines for Implementation of Duties and Administration of Religious Courts". It has been revised in 2006, 2010, and 2013. It was incomplete norm because Marriage Law does not explain the division of community property in polygamous marriages. It only contains the requirements of polygamy, so that it is not legal and could not protect the wife. The research method used by the author in this study was normative or doctrinal legal research. It was concluded that division of community property is the absolute requirement in polygamy, in order to protect the rights of wives. It is based on Marriage Law, Compilation of Islamic Law and Supreme Court Decision of the Republic of Indonesia Number KMA/032/SK/IV/2006. In terms of polygamy, Religious Courts also provide a verdict in the form of stipulation of community property. This is in line with the concept of legal protection which provides protection through legal certainty and guarantees justice for wives.
\end{abstract}

Keywords: legal protection, polygamy, community property.

DOI: $10.7176 / J L P G / 94-23$

Publication date: February $29^{\text {th }} 2020$

\section{CHAPTER I: INTRODUCTION}

Of the various aspects that have been regulated, marriage is a sunnatullah, which generally applies to all creatures of Allah SWT. Islam has rejected other ways besides marriage to fulfill the biological needs of humans, which means that humans are not allowed to do other things than marriage to fulfill their biological needs. ${ }^{1}$

Whereas, according to fiqh, as mentioned by Soelaiman Rasyid, marriage is a contract that justifies association and limits the rights and obligations between a man and a woman who is not his/ her mahram. ${ }^{2}$

Based on Law No.1 of 1974, marriage is an inner and outer bond between a man and a woman as a husband and wife in order to build a happy and eternal family based on the Supreme Lord. ${ }^{3}$

Happy family, which is the goal of marriage, can be realized by fulfilling a number of things; one of which is by fulfilling material needs. Therefore, it can be seen that the husband is obliged to spend upon the family; it is not is the responsibility of the wife.

In the positive law that applies in Indonesia, the understanding of community property is contained in article 35 paragraph (1) of Law Number 1 of 1974 concerning Marriage, which states: "Property acquired during marriage becomes a common property".

\footnotetext{
${ }^{1}$ M. Thalib, Perkawinan Menurut Islam, (Surabaya: Al Ikhlas, 1993), page 1.

${ }^{2}$ H. Soelaiman Rasyid, Figh Islam, (Jakarta: Attahiriyah, 1997), page.374

${ }^{3}$ Law Number 1 of 1974 on Marriage Article 1
} 
The provisions of article 1 letter f on Compilation of Islamic Law appear to be more moderate, because the article requires that assets acquired during a new marriage can be seen as community property if they are collected by the husband and wife efforts, both individually and collectively. Article 1 letter f Compilation of Islamic Law may lead cases between the husband and wife.

This article is contradictory to article 35 paragraph (1) of the Marriage Law above considers all revenues during marriage to be community property without taking into account the original owner. Thus, to avoid legal contradictions, the only way that can be taken is to compromise those two provisions, by taking into account article 34 paragraph (1) and paragraph (2) of the Marriage Law, which states that, paragraph (1): "Husband is obliged to protect his wife and provides all the necessities of the family, "Paragraph (2):" The wife is obliged to arrange household affairs as well as possible." Thus, even though the wife does not make money, all the assets obtained during marriage is still considered as community property, and if they are divorcing, the wife still gets a share of the community property, as stipulated in article 37 of the Marriage Law; each of them gets a half of the community property, as stipulated in Compilation of Islamic Law article 95 and article 97. This is based on the legal logic that in principle, the husband and the wife has their own duty; therefore, each of them is entitled to obtain the same share of the assets acquired during their marriage. ${ }^{1}$

Polygamy is a reality in society which has recently become a big issue. It has caused pros and cons. Polygamy itself refers a marriage between one man and more than a wife. In article 3 paragraph (2) of Law Number 1 of 1974 concerning Marriage, it is possible for a man to marry more than one woman; it is also called polygamy, which is one of the manifestations of Islamic marriage law. In article 4, it is also stated that: if a husband intends to have more than one wife, he must submit a written request to the Religious Court.

Polygamy ${ }^{2}$ is a marriage where a husband marries more than one wife. Can he treat his wives justly?

This is explained by Allah SWT in An-Nisa 'verse 3, "And if you fear that you will deal justly with the orphan girls, then marry those that please you of (other) women, two or three or four. But if you fear that you will not be just, then (marry only) one or those your right hand possesses. That is more suitable that you may not incline (to injustice). ${ }^{3}$,"

At the last level, community property will become a disputation. It is inevitable that the judicial institution will play a role in the dispute resolution process referred to above. Article 35 of the Marriage Law paragraph (1) states: Community property is property acquired during marriage. ${ }^{4} \mathrm{M}$. Idris Ramulya defines community property as goods which are acquired after a woman and a man are married, either one's or theirs. ${ }^{5}$

Marriage Law No. 1 of 1974 regulates property in marriage in Chapter VII Article 35, Article 36 and Article $37{ }^{6}$

The rules of those articles basically provide a pretty clear description. If it is analyzed further, it turns out that article 37 of the marriage law does not provide positive legal uniformity about how to distribute community property and settle the problems occur in a divorce.

KHI article 94 states that community property in polygamous marriages are separated; the second wife and onwards d not have the right. However, there is an opinion stating that article 94 is unfair for the first wives because they receive the least portion among other wives. In fact, the first wife accompanied the husband for a longer time, and continued to accompany him even after the next marriage. Of course it is considered unfair because the first wife suffers the most, especially in terms of mental condition. After all, no woman wants to share her husband with other women.

The establishment of community property in polygamous marriages is contained in Law 1/1974 concerning Marriage, Compilation of Islamic Law (KHI) and even in the Administrative and Technical Handbook of Religious Courts applied in the Religious Courts based on the decision of the chairman of the Supreme Court Number:

\footnotetext{
${ }^{1}$ Ibid

${ }^{2}$ Siti Musdah Mulia, Islam Menggugat Poligami, (Jakarta: PT. Gramedia Pustaka Utama, 2007), 43

${ }^{3}$ Departement of Religious Affairs of the Republic of Indonesia, Al-Qur'an and its Translation., 30

${ }^{4}$ Siti Musdah Mulia, Posisi Perempuan dalam Hukum Islam di Indonesia,(Jakarta: Kencana, 2008), page.134

${ }^{5}$ M. Idris Ramulya, Hukum Pekawinan, Hukum Pewarisan, Hukum Kewarisan, Hukum Acara Peradilan Agama, (Jakarta: Sinar Grafika, 1995), page. 29

${ }^{6}$ H.M.A. Tihami, M.A.,M.M, Fikih Munakahat (Jakarta: PT.Raja Grafindo Persada, 2008), page. 179.

Article 35 states: (1) All property obtained during marriage is considered as community property, (2) The property of the husband and wife (before the marriage) obtained from inheritance and gift is under each ownership.

Article 36 states: (1) Community property depends on the agreement of both parties (the husband and wife), (2) Each party has full right of their own personal property.

Article 37 states: If the marriage is ended due to divorce, the community property is regulated in accordance to the law.
} 
KMA/032/SK/IV/2006 concerning the enactment of "Book II Guidelines for the Implementation of Duties and Administration of Religious Courts". It has been through several revisions; the first one was in 2006, the second was in 2010, and the last was in 2013. It was incomplete because the Marriage Law does not specify provisions regarding the division of community property in polygamous marriages; it only regulates conditions for polygamy.

Actually, KHI included community property, but the stipulation and division of community property were not specified, so that they were not legal and could not protect the wife.

Book II of the Guidelines contains details and orders that in deciding polygamy applications, the PA must have community property without legal certainty because their position is not an obligation proven in the decisions of PA judges who do not always require the inclusion of community property in polygamy as a consideration in deciding the application.

These conditions are contained in the Guidelines for the Implementation of Duties and Administration of Religious Courts, Book II. However, the influence of these conditions on the polygamy permission has not been proven, in terms of the minimum wealth that must be possessed in order to carry out polygamy. The implementation of community property in the application of polygamy was not clearly written in Book II of the Guidelines for the Implementation of Duties and Administration of Religious Courts. The determination of community property, which was stipulated in the Marriage Law, can be determined after the divorce or death. Therefore, the stipulation becomes a vogue of norms on the establishment of community property in polygamous marriages, so that the legal protection of the wives is also likely not fulfilled.

Besides the juridical problems above, there are also some philosophical problems, namely: Ontologically, the essence of marriage is to realize the goal of marriage, as well polygamous marriage. One of the influences is community property. Community property in polygamous marriage must be regulated in the law. Epistemologically, the arrangement of the community property in polygamous marriages has not provided legal certainty, which results in decisions that are disparate and lead to unclear norms or even norm conflicts. Axiologically, in order to ensure a sense of justice, legal certainty and legal protection of the position of community property in polygamous marriages must be regulated in law that also has legal certainty in order to avoid a disputation. In this study, the sub-problems are formulated as follows: How is the urgency of the division community property in applying for polygamous marriages that provide legal protection for wives? What is the substance of the division of community property in applying for polygamous marriages?

\section{MATERIAL AND METHOD}

According to Peter Mahmud, "Legal research is a process to find legal rules, legal principles, and legal doctrines in order to answer legal issues faced". ${ }^{1}$ Legal research is the method of scholars; one of which is characterized by the use of methods. The legal research method is a systematic way of conducting a study. ${ }^{2}$ The research method used by the researchers of this study was normative or doctrinal legal research. According to Terry Hutchinson, as quoted by Peter Mahmud, Marzuki defines that doctrinal law research is as follows:

"Doctrinal research: Research that provides a systematic exposition of the rules of governing a particular legal category, analyses the relationship between rules, explain the area of difficulty and, perhaps, predicts the future development.". 3

In this study, the approach method used is a normative legal research. ${ }^{4}$ To get the clarity from various aspects related to the problems to be studied, the problem approach that will be used in this study includes: philosophical approach, conceptual approach, statue approach ${ }^{5}$, case approach and historical approach. ${ }^{6}$

Based on the indicators contained in the title of this study and the types of approach methods in legal research, thus approach method used in this study focused on philosophical approach, statute approach, conceptual approach, and case approach by analyzing judges' decisions about the application for polygamous marriages. The researchers will attempt to discuss the Marriage Law and regulations that support it as well as conduct a discussion

\footnotetext{
${ }^{1}$ Peter Mahmud Marzuki,Penelitian Hukum, Kencana Prenada Media Group, Jakarta, 2011, page 35

2 Abdulkadir Muhammad, Hukum dan Penelitian Hukum,PT.Citra Aditya Bakti, Bandung,2004, page.57

${ }^{3}$ Peter Mahmud Marzuki.Op.cit., page. 32

${ }^{4}$ Ronny Hanitijo Soemitro, Metodologi Penelitian Hukum dan jurimetri cetakan ketiga, (revised), Ghalia indonesia, 1998, page. 11

${ }^{5}$ Johnny Ibrahim, Teori \& Metodologi Penelitian Hukum Normatif, (Malang, Buyumedia Publishing, 2008), page 310-320

${ }^{6}$ Peter Mahmud Marzuki, Op.Cit, page 119 \& 126
} 
of the philosophical approach in order to answer the problems in the division of community property in polygamous marriages that guarantee the legal protection for wives.

The legal material collection technique used in this study was library research, which is to collect, study and review legal materials that is related to the problems formulated, both primary legal materials, secondary legal materials and tertiary legal materials. ${ }^{1}$

The primary legal material that was used in this study included the 1945 Constitution of the Republic of Indonesia, civil law related to the division of community property in polygamy (including Civil Code, HIR, and Law No. 1 of 1974), other related regulations (Compilation of Islamic law and Book II of the Guidelines for the Implementation of Duties and Administration of Religious Courts), as well as the law that regulates the authority of religious court in dealing with marital issues (including laws on PA, judicial authority, and other supporting regulations).

The secondary legal materials included the opinions of scholars and legal experts who are competent in community property and polygamy, literatures on law, administrative law and legal theory, dissertations, theses and research reports, journals, articles, and internet.

Tertiary legal materials are like the results of research, the scientific work of scholars, including international documents in the form of both resolutions and conventions. Tertiary legal materials used in this study included: Indonesian dictionary; legal dictionary; dictionary of civil law; English dictionary; encyclopedia; catalog list.

In this study, the legal material obtained will be presented qualitatively, described systematically, and then analyzed qualitatively. In qualitative juridical analysis methods, the data or research objects are not only described as they are, but there should be argumentation about the division of community property in polygamous marriages that guarantees legal certainty and legal protection for wives.

\section{DISCUSSIONS}

The urgency of the division of community property in polygamous marriages that provide legal protection for wives suggests that the provisions governing the issue of joint property in polygamous marriage arrangements are regulated so easily and publicly, so that they can lead to a disparate interpretation. Article 94 on Compilation of Islamic Law regulates the following: (1) Community property in polygamous marriage is separated and independent. (2) The ownership of the community property of polygamous marriage as mentioned in paragraph (1) is calculated on the second, third or fourth marriage contract.

The above conditions are very general and simple. Therefore, the Supreme Court of Indonesia, in the Decree of the Chief Justice of the Supreme Court Number: KMA/032/SK/IV/2006 dated April 4, 2006, has implemented Book II concerning the Court's Implementation and Administration Guidelines, which contains the issue of community property in polygamous marriages. The provisions are regulated as follows: ${ }^{2}$

a. When submitting a polygamy application to the Religious Court/Syari'ah Court, the husband is also obliged to submit a request for the division of community property with the previous wife together as well as the consent. If the husband does not submit it, then the previous wife (who has not been divorced) can file a claim on the reconciliation of community property determination. If the previous wife did not file a reconciliation claim, then the polygamy application must be declared unacceptable (Niet Ont Vanklijk Verklaard).

b. The community property obtained during marriage with the first wife must be separated from the community property with the second wife and onwards.

The Supreme Court regulates community property in polygamous marriages as mentioned above so that the husband cannot smuggle his previous wife's rights. Therefore, the Supreme Court requires a strict separation between the property of the husband and the previous wife when the husband will conduct polygamous marriage. Therefore, Islam strongly requires a neat and accountable ${ }^{3}$ bookkeeping made by a husband and wife who have the community property, so that there the property is separated from the others' wives. Thus, the first wife's rights in community property are more secure, after being determined by the Religious Court.

\footnotetext{
${ }^{1}$ Soerjono Soekanto, dan Sri Mamudji, Penelitian Hukum Normatif Suatu Tinjauan Singkat, Raja Grafindo Persada, Jakarta, 1995, page. 24

${ }^{2}$ The Supreme court of the Republic of Indonesia, Buku II Pedoman Teknis Administrasi dan Teknis Peradilan Agama,(2008), page.130-134.

${ }^{3}$ Surah Al-Baqarah (2):282
} 
Based on Law Number. 11974 The Marriage Law, the division of community property was not clearly regulated; only article 35 states that the community property is assets obtained by the husband and wife during their marriage. The division of community property in polygamous marriages has been regulated in article 94 Compilation of Islamic Law, but it is injust, because in certain circumstances, the first wife is being disadvantaged.

Article 4 paragraph (1) Marriage Law Number. 1 of 1974 stated that a person who wants to do polygamous marriage must obtain the permission from the local Religious Court. This means that someone who wants to do a polygamous marriage must submit a polygamy application prior to the marriage. ${ }^{1}$

Basically, there are no legal provisions or laws that regulate community property in the application for polygamous marriages. This is only an appeal from the Supreme Court and is an interpretation of article 94 of the Compilation of Islamic Law with the suggestion that the application should include the community property obtained with the previous wives. Based on the request of the husband, Religious Court determines the community property he obtained with his previous, so that they cannot be claimed by the new wife.

This is in accordance with article 136 paragraph (2b) Compilation of Islamic Law Jo article 78 point (b) Law No. 7 of 1989 Jo Article 24 paragraph (2c) Government Regulation No. 9 of 1975 which states:

"During the divorce lawsuit, at the request of the plaintiff, the court can determine matters that are necessary to ensure the goods which are classified as community property, husband's property or wife's property." ${ }^{2}$

However, the division of community property in polygamous marriage should guarantee and protect the rights of the first wife or the previous wives.

KMA/032/SK/IV/2006 is the Supreme Court's decision regarding the enactment of Book II guidelines for the implementation of duties and court administration, as well as the development of positive law on the provisions in Islamic Law. Whereas, the purpose of Book II is based on the need to stipulate further improvements that are solid, clear and explicit, which must be carried out by all structural and functional officials and all judicial officers uniformly, disciplinely, orderly and responsibly.

Basically, there are no legal provisions or laws that regulate community property in the application for polygamous marriages. This is only an appeal from the Supreme Court and is an interpretation of article 94 Compilation of Islamic Law, namely the community property of polygamous marriage. Community property is separated and independent, which is calculated in the second, third or fourth marriage contract. It is suggested that the polygamy application should include assets obtained with the previous wives. Based on the husband's request, Religious Court determines the community property obtained with the previous wives, so that it cannot be claimed by the new wife. ${ }^{4}$

Article 3, 4 and 5 of the Marriage Law Number 1 of 1974, basically states that the Court allows polygamous marriages. This permit is issued if the wife concerned is sick and cannot serve her husband, infertile, or is unable to carry out her duties as a wife for other reasons. In polygamy, wife's consent is also required. However, it is not needed if the wife cannot give her consent. This article shows that marriage is solely intended to fulfill biological interests and to obtain heirs/ descendants.

Some of the divorce cases that occur are due to polygamy. Even sometimes polygamy is carried out secretly, without the consent of a legitimate wife, causing the husband neglect his legal wives. This shows that rights of women are not guaranteed, both in legal marriage and unregistered marriage.

To prevent that kind of marriage, that does not protect the right of the wife, both the legal wife and other wives, women should be encouraged to refuse any kind of violent in marriage. Therefore, the judiciary must attempt to maximize law enforcement and prioritize women protection in handling cases which place women as victims, both in institutions and marriage.

From the reason above, the stipulation of community property is required for someone who wants to submit a polygamy application. This aims to make it difficult for someone when they want to do polygamy. Without the determination of community property, the application can be rejected by the court. Basically, the ones who are often disadvantaged in polygamous marriages are women, especially first wives. Second, if the polygamous marriage is really done, the community property has been divided fairly according to the provisions of the applicable law.

\footnotetext{
${ }^{1}$ Marriage Law Number. 1 of 1974

${ }^{2}$ Ibid

${ }^{3} \mathrm{KMA} / 032 / \mathrm{SK} / \mathrm{IV} / 2006$

${ }^{4}$ RAKERNAS MARI, Makalah Pembanding Perdata Agama, page 8
} 
Before the enactment of Book II and referring to article 94 Compilation of Islamic Law, community property for the wives is separated and independent. However, after the publication of KMA/032/SK/IV/2006 concerning the enactment of Book II in the guideline of polygamy letter (b) point (4), it is stated that the ones being disadvantaged are the first wives; therefore, the article must be interpreted as stipulated in point (5). In point (5), it is explained that the assets obtained by the husband during his marriage with the first wife are property of the husband and first wife. Whereas, the property obtained by the husband during his marriage with the second wife, as the husband is still bound by marriage with the first wife, then the property is the community property of the husband, first wife and second wife. According to these provisions, the community property should be divided properly because it is collected by the first wife and the husband; thus, it would feel unfair if the property had to be divided according to the provisions contained in the Compilation of Islamic Law, which is divided separately and independently.

To protect the rights of the previous wives, all the provisions contained in Book II are correct because as explained in KMA/032/SK/IV/2006, the provisions contained in Book II considered to have fulfilled the requirements used by the Supreme Court, specifically the division of community property in the application for polygamous marriage. ${ }^{1}$

In Book II, it is stated that the application for polygamy is a controversial case (lawsuit), but the position of the wife is the defendant; the wife is obliged to conduct reconciliation if the husband does not submit a community property determination, because basically reconciliation is only intended for cases that are controversial or a claim. $^{2}$

Book II requires that the husband also should submit a stipulation of community property together with his previous wife, or community property with his previous wives. Otherwise, his wife or wives can submit community property reconciliation. In that case, the application for polygamous marriage must be rejected. ${ }^{3}$

Before the publication of KMA/032/SK/IV/2006 concerning the enactment of Book II, the conditions for submitting a polygamy application only referred to article 4 and article 5 of the Marriage Law Number 1 of 1974 Jo article 56, article 57 and article 58 Compilation of Laws Islam Jo article 40 and article 41 of Government Regulation Number 9 of 1975 concerning the implementation of Law Number 1 of 1974 concerning marriage; first, a person who wishes to conduct polygamous marriage must submit an application to the court in his domicile. Secondly, a person who has applied for a polygamous marriage is accepted by the court if the wife cannot carry out her duties as a wife, the wife gets a disability or an incurable disease, and the wife cannot give birth to children. Third, there is consent from the previous wife or wives, there is a guarantee that the husband is able to fulfill the necessities of life for his wives and children, and there is a guarantee that the husband will treat his wives and children justly.

Some differences in arrangements between before and after the publication of KMA/032/SK/IV/ 2006 concerning the enactment of Book II, especially application for polygamous marriage, namely first, the application for polygamy permits must be controversial, the wife must be placed as the respondent. Second, the reason for polygamy permits regulated in Article 4 paragraph (2) of Law Number 1 of 1974 is facultative, meaning that if one of these requirements can be proven, the Religious Court grant the application. Third, the polygamy permit requirements stipulated in article 5 paragraph (1) of Law Number 1 of 1974 are cumulative, meaning that religious courts can only grant polygamy if all of the requirements are met. Fourth, community property if the husband has more than one wife has been regulated in Article 94 Compilation of Islamic Law, but the article is unjust, because in certain circumstances, it can disadvantage the first wife; therefore, the article must be described in number (5) below. Fifth, the property obtained by the husband during his marriage with the first wife is the community property the husband and his first wife. Whereas, the property obtained by the husband during his marriage with the second wife, as the husband is still bound by marriage with his first wife, then the property is considered community property of the husband, first wife and second wife. Sixth, the provisions of the community property in number (5) do not apply to assets for the second, third and fourth wives (such as houses, furniture and clothing) as long as the assets designated for the second, third and fourth wives do not exceed $1 / 3$ of the community property of the husband and the second wife, third wife and fourth wife. Seventh, the community property for a husband who has more than one wife due to death or divorce, then the calculation is as follows: for the first wife, $1 / 2$ of the community property, then added by $1 / 3 x$ community property of the husband and the first wife and second wife, then added by $1 / 4 \mathrm{x}$ of community property of the husband and the first wife, second wife and third wife, then added by $1 / 5 x$ of community property of the husband and the first wife, second wife, third wife, and fourth wife. Eighth, the assets obtained by the first wife, second, wife, third wife, and fourth wife is considered community property, unless if those are gifts or inheritance. Ninth, the husband also should submit a stipulation of the

\footnotetext{
${ }^{1} \mathrm{KMA} / 032 / \mathrm{SK} / \mathrm{IV} / 2006$

${ }^{2}$ Buku II Pedoman Teknis Administrasi dan Teknis Peradilan Agama, page.130

${ }^{3}$ Buku II Pedoman Teknis Administrasi dan Teknis Peradilan Agama, page.13
} 
community property with his previous wives. Otherwise, his wives can submit community property reconciliation. Tenth, if the husband does not submit a community property stipulation, the application for polygamous marriage, and if the previous wife does not submit reconciliation on community property determination in the case of polygamy application as referred to in number (9) above, the application must be rejected.

Determination of community property in polygamy is very appropriate in the perspective of Islamic Law; this is in accordance with the rules of maslahah mursalah or general welfare, namely that the formation of law is not intended except to create benefit in society in order to bring benefits to them while eliminating losses and difficulties of the community. This can be seen from the benefits of the application of Book II by $\mathrm{KMA} / 032 / \mathrm{SK} / \mathrm{IV} / 2006$, especially in terms of polygamy application, which include the protection of women (in this case is the first wife including the children who are disadvantaged. This is in accordance with Surah An-Nisa 'verse 9:

Meaning: Let those people fera (injustice) as if they (themselves) had left weak offspring behind and feared for them. Let them fear Allah and let them speak words of appropriate justice. ${ }^{l}$

The considerations are the provisions of permanent legal certainty that are protective against the rights of the first wife, namely in the form of community property stipulation in the application for polygamy permit, that has gone through a process that is so selective and effective, as carefully mandated by KMA/032/SK/IV/ 2006. It is aimed to avoid polygamous marriages that violate the legal provisions by being unfair to their wives, especially the first wife. Justice is very difficult to realize. Similarly, the difficulty of being just and fair in polygamous marriage is explained by Allah SWT in Surah An-Nisaa 'verse 129:

Meaning: And you will never be able to be equal (in feeling) between your wives, even if you should strive (try to do so). Therefore, do not incline completely (toward one of them) and leave another hanging. And if you amend (your affairs) and fear Allah - then indeed, Allah is ever Forgiving and Merciful. ${ }^{2}$

The substance of the division of community property in polygamous marriages that provide legal protection for wives suggests that judge's decision is just if it contains proportional elements of justice, benefit, and legal certainty. A judge's decision must be fair, but it must also be beneficial for the concerned and for the community; it should have legal certainty.

Judge's consideration in determining community property in polygamous marriage, with the presentation of the above theories has actually been accommodated and in accordance with the theory of maslahah in ushul fiqh. AlButhi and al-Ghazali stated that: ${ }^{3}$

Meaning: If you get benefit, then there is God's law.

According to al-Bûthi, maslahat is the benefit of being the goal of as-Syâri "for His servants, in order to protect their religion, soul, mind, offspring and property and their implementation as the order above. If we pay attention to the shari'a of Islam, then we will not get a law that does not encourage us to live better, for humans in general. Therefore, tasyri 'al-hukm and abolition (naskh) reinforce that Islamic law is merely intended to protect the benefit of its adherents. So that, a law is not called maslahat if it does not bring benefits and eliminate disadvantages. ${ }^{4}$

The relationship between maslahat and the purpose of law (maqasid syariah) is a symbiotic relationship. Those two need each other. It means that maslahat requires the purpose of law (maqasid syariah); on the other hand, the purpose of the law and order also requires maslahat. ${ }^{5}$

This can be seen from the benefits of the application of Book II by KMA/032/SK/IV/2006, especially in terms of the application of polygamous marriage, which include the protection of women (in this case is the first wife and also the children who also feel disadvantaged); therefore, the community property is divided justly and clearly. Therefore, to protect the rights of the first wife, the establishment of community property is one of the steps in the application of polygamous marriage. If the husband does not submit the division of community property, then it cannot be accepted (Niet ontvankelijke verklaard/ NO). It aims to secure or protect the existence and integrity of community property.

In addition, the opinions of judges regarding the division of community property in the application of polygamous

\footnotetext{
${ }^{1}$ Departement of the Religious Affairs of the Republic of Indonesia, Al-quran and its translation.

${ }^{2}$ Ibid

${ }^{3}$ Ahmad Ali, Menguak Tabir Hukum, page 85.

${ }^{4}$ Abu Ishaq Al Syatibi, Almuwafaqat fi Ushul Al-Syari'ah, I ${ }^{\text {st }}$ Edition, Cet. III, page 195

${ }^{5}$ Ibid
} 
marriages are based on good benefits, because policies aimed at achieving benefit should be supported, in accordance with the following:

Meaning: government policy (Judge) against the people (the applicant and the respondent (full) must pay attention to the benefit.

Every action or policy of the government that concerns and is related the rights of the people is associated with the benefit of the masses. It is intended to bring goodness. The government is the person in charge of the people (ummah); therefore, each policy must pay attention to benefit, because the law will not be implemented properly if no one is responsible for controlling, implementing and enforcing it. Therefore, it is believed that leadership is part of the most urgent goal in religion, in this case is the government. Whether this government policy is right and wrong in the perspective of Shari'a of Islam depends on its benefits of the policy for the people. If it is a beneficial for the people, then it is true. Otherwise, if it is not beneficial, it is not true. The policy is associated with benefit, because leaders work not for themselves, but as representatives of the people. ${ }^{1}$

Similarly, in deciding cases, the judges are not bound by any legal rules but are seen as a situation because the judge is not the mouthpiece of the law but the one who created the law. It is also possible for a judge to decide a case using customary law, positive law, clerics' opinions, as well as Al-Qur'an or hadist. The judge must have a legal basis in deciding a case. In deciding a case, the Judge must always explore and apply the existing laws and find new laws that are in accordance with the applicable laws in the society, which are beneficial.

If the existing provisions of the Law is in contrary with the public interest, propriety, civilization and humanity, namely the values that live in the community, according to Yahya Harahap, the Judge is free and has the authority to take contra legem or interpretation of the law. ${ }^{2}$ Judges' decisions may not only fulfill legal formalities or just maintain order, but they must be able to fulfill legal certainty and a sense of justice. Judges must explore, follow and understand the legal value and sense of justice that lives in a society that brings benefit.

In the aspect of legal discovery, the judge used the legal construction, because originally, polygamy was constructed as a voluntary case, but now construction is no longer permissible but the term is termed Petitioner and Respondent. Previously, application for polygamous marriage did not need the division of community property, but now it becomes one of the requirements, in order to protect women, as intended by Law No.1 of 1974. Therefore, legal construction can be used by judges as a method of legal discovery if in adjudicating cases, there are no rules that specifically regulate the events that occur that benefit the justice seeker.

Explain the decisions of the Religious Courts about permits for polygamy which have different considerations.

Affirming the authority of the religious court to enforce law and justice regarding certain cases is intended to provide a legal basis for resolving cases of violations of the Law, which are the authority of the Religious Courts, such as violations of the marriage law and so forth.

The Supreme Court added one more requirement that must be fulfilled as submitting the application for polygamy to the court, namely: "As applying polygamous marriage, the husband is obliged to also apply for the division of the community property of the husband and his previous wives. Otherwise, his wives can submit a reconciliation agreement on community property. If the husband does not the division of community property as well as the application for polygamous marriage, while the previous wife did not file a reconciliation claim on the division of community property, then the application is rejected. "3

Therefore, in the application for polygamy, it is required that the husband should also submit the division of community property. This bases its considerations in Book 2 of the Guidelines for the Implementation of Duties and Administration of Religious Courts, where there are provisions that include the division of community property conducted by the Religious Courts as one of the conditions for applying for polygamy. If it is not included, then the application for polygamy is rejected/ NO (on vankelijke verklaard).

\section{Some Decisions of the Religious Courts Regarding the Application of Polygamy}

1. Decision of Religious Court of Jombang Number: 022/Pdt.G/2009/PA.Jbg.

\footnotetext{
${ }^{1}$ Abdul Mudjib. Kaidah-kaidah Ilmu Fiqh, (Jakarta: Kalam Mulia, 1996), page 61-62

2 Yahya Harahap, Kedudukan dan Kewenangan dan Acara Peradilan Agama., page 75.

${ }^{3}$ Drs H.M.Anshary, MK.,SH.,M., Harta Bersama Perkawinan dan Permasalahannya, Mandar Maju, Bandung, cet.1 2016, page. 83
} 
Regarding the Law, during the marriage between the Petitioner and the Respondent, a community property has been produced. Verdict: The division of the community property of the Petitioner and Respondent is: 1 . A house with a size of $5 \times 10 \mathrm{~m}$, which is located in Jombang Regency, with boundaries: Its north is Sumilah's house; Its east belongs to Misti; Its south belongs to Misti; Its west is Suryadi's; 2. Two beds; 3. Two Cupboards; 4. One set of table and chair;

In the formulation of the application for polygamy marriage above, the decision contains the provisions for the determination of community property because the decision of the Religious Court was taken after the issuance of $\mathrm{KMA} / 032 / \mathrm{SK} / \mathrm{IV} / 2006$, so that there is an requirement to Determine Community Property in the Application for Polygamy. However, there is no description of the judge's consideration as to why there is a stipulation of community property in the decision to approve the application for polygamy. This implies that the decision to grant polygamy is based on the division of community property, but there is no explanation about this. It might lead to an injustice, such as the community property referred to are based on the provisions of community property in article 35 of the Marriage Law, where the community property is mentioned as assets obtained by the husband and wife during the marriage. The origin of the assets obtained is not mentioned; for example, if the husband does not work or if the wife's income is greater. Actually, there are provisions in Article 65 paragraph (1) of the Marriage Law and Article 94 Compilation of Islamic Law.

\section{Decision of the Religious Court of Malang Regency Number: 6698/Pdt.G/2017/PA.Kab.Mlg..}

About Legal Consideration: Considering that because the Petitioners' petition for polygamy is granted, it is necessary to have legal certainty regarding the status of the assets obtained by the Petitioner and Respondent during marriage. This is in accordance with the Decree of Chairman of the Supreme Court of Indonesia Number KMA/032/SK/IV/2006 April 4, 2006 concerning Enactment of Book I of the Duty Implementation Guidelines and Court Administration; Considering that the Petitioner requested that the assets acquired during the marriage with the Respondent should be determined as community property between the Petitioner and the Respondent, as the posita of the Petitioner's petition point 9; Considering, that in this case the Panel of Judges needs to present the provisions in Article 94 of the Compilation of Islamic Law "paragraph (1) that the community property of a husband who has more than one wife is separated and independent; paragraph (2) that the community property of a husband who has more than one wife as referred to in paragraph (1), calculated at the second, third and fourth marriage contract. Considering, that based on the provisions of Article 94 of the Compilation of Islamic Law, the Panel of Judges assume that the assets obtained by the husband during his marriage with the first wife is community property of the first husband and his first wife, while the property obtained by the husband during his marriage with the second wife, when the husband is still bound by marriage with his first wife, then the property is a community property of the husband, the first wife and second wife. The same thing applies for the third and fourth wife; Considering that in relation to this case, the assets mentioned by the Petitioner and the Respondent above are houses with Property Rights Certificate Number 02379, with an area of 77 M2, the Panel of Judges determines that the property is community property of the Petitioner and Respondent, which will be stated in the case of this Decision, and the prospective second wife of the Applicant does not has any right to it; Considering that based on the aforementioned considerations, the Panel of Judges believes that the Petitioner's petition to determine community property between the Petitioner and the Respondent in the form of a house with Property Rights Certificate Number 02379, with an area of $77 \mathrm{~m}^{2}$ can be granted; Decision: 1. To grant the Petitioner's Request; 2. To give permission to the Petitioner, DEDY DWI WIBAWANTO bin SOEHARDJONO, to remarry/ polygamy SRIWAHYU WIJI NINGSIH binti SUNTARI; 3. To determine community property of the Petitioner and the Respondent as follows: a house with area of $77 \mathrm{~m}^{2}$ located in Perum Asrikaton Indah H-8/3 RT.06 RW.09 Asrikaton Village, Pakis Sub-district, Malang Regency, with the following boundaries: East: Mr. Edi's land; South: Mr. Heri's land; West: Mrs. Titin's land; North: Streets.

In this second decision, the basis for the decision on community property, KMA/032/SK/IV/2006 dated April 4, 2006 and Article 94 Compilation of Islamic Law has been issued. However, it cannot provide legal certainty and legal protection because Article 94 of Compilation of Islamic Law has not clearly regulated the community property in detail; in fact, it can lead to multiple interpretations. The cleare provisions can be seen in $\mathrm{KMA} / 032 / \mathrm{SK} / \mathrm{IV} / 2006$, namely on community property that is more detailed. However, KMA/032/SK/IV/2006 is clearly not a source of law that can be the basis of a decision. KMA is just a guideline for administration of judges.

From the decision on the application for polygamous marriage above, it can be seen that a Court of Religion Implementation Book and Administration Guidance Book, which was revised in 2010, states that the husband should submit an application for the division of community property with his previous wives as submitting the application for polygamous marriage. Otherwise, his wives can submit a reconciliation agreement on community property. If the previous wife did not submit a request of community property reconciliation, the 
application for polygamous marriage must be rejected (neit ontvanklijk verklaard). ${ }^{1}$

Judge has good understanding on law, so that whatever problems are raised to him, he is obliged to find the law. It is the judge's obligation to explore the legal values that live in society; in other words, the judge acts as a law-maker. Judge is not only as a mouthpiece for law and should not too focus on positive law. Usually, if there is no concern on living law, there will be lack of justice in the society. ${ }^{2}$

The judges have to explore legal discovery and the creation of law by paying attention to the values of unwritten law and a sense of justice in the community, so that it functions jurisprudence as a source of law in Indonesia. Judges should not act as a mouthpiece for law, but they have to interpret the law actually in accordance with the needs and developments that occur amidst the lives of the society, while taking into account the aspect of justice, legal certainty and value of its benefits. In deciding a case, a judge must always explore and apply the existing laws and find new laws that are in accordance with the laws that apply in the society. It means that the judge's decision is not merely fulfilling the legal formalities.

\section{CONCLUSIONS AND SUGGESTIONS}

The urgency of determining community property in the application of polygamous marriage that provides legal protection for the wives include the obligation to separate property as an absolute requirement for just and fair polygamous marriage, in order to protect the rights of wives, both first wives and the next wives. It also includes the determination of community property based on legal rules that are recognized and supported by the officials and the community, which leads to legal certainty.

The substance of the division of community property in polygamous marriage is based on the Marriage Law, Compilation of Islamic Law and Supreme Court Decision of the Republic of Indonesia Number KMA/032/SK/IV/2006. Almost all the decisions of the Religious Courts regarding the Application for permission for polygamy also provide a verdict in the form of stipulation of community property. This is in line with the concept of legal protection which provides protection through legal certainty and guarantees the right of the wives.

Since the law regarding community property in polygamous marriages has not been regulated in the Marriage Law, then the Compilation of Islamic Law is also incomplete and is still very multi-interpretation, it is necessary to make additional rules regarding community property in polygamous marriages, so that they can support legal certainty for parties involved in polygamous marriages.

According to the Government of the Republic of Indonesia and DPR RI, that the Compilation of Islamic Law with status of INPRES Number 1 of 1991, which has been guiding judges in the Religious Courts in Indonesia in examining and deciding cases related to inheritance, thus The Executive (President) and the Legislature (DPR RI) should include INPRES into the law.

According to the Decision of the Chief of the Supreme Court of Republic of Indonesia Number $\mathrm{KMA} / 032 / \mathrm{SK} / \mathrm{IV} / 2006$, community property in polygamous marriages is not a requirement in the application of polygamous marriage. If it is used by the judges in considering the application, it will lead to legal uncertainty. Therefore, it is necessary to include this in the law.

\section{REFERENCES}

Abdul Mudjib. Kaidah-kaidah Ilmu Fiqh, (Jakarta: Kalam Mulia, 1996)

Abdulkadir Muhammad, Hukum dan Penelitian Hukum,PT.Citra Aditya Bakti, Bandung,2004

Abu Ishaq Al-Syatibi, Almuwafaqat fi Ushul Al-Syari'ah, Jilid I, Cet. III.

Achmad Ali, Menguak Tabir Hukum, (Suatu Kajian Filosofis dan Sosiologis), PT. Toko Gunung Agung Tbk, Jakarta, cet.II 2002

Drs. H.M. Anshary, MK.,SH.,MH., Harta Bersama Perkawinan dan Permasalahannya, Mandar Maju, Bandung, cet. 12016

H. Soelaiman Rasyid, Fiqh Islam, (Jakarta: Attahiriyah, 1997)

H.M.A. Tihami, M.A.,M.M, Fikih Munakahat (Jakarta: PT.Raja Grafindo Persada, 2008)

\footnotetext{
${ }^{1}$ Drs.H.M. Anshary, Harta Bersama Perkawinan dan Permasalahannya, Mandar Maju, Bandung, cet.1 2016, page 89

${ }^{2}$ Taufik Hamami, Mengenal Lebih Dekat Kedudukan dan Eksistensi Peradilan Agama Dalam Sistem Tata Hukum di Indonesia.
} 
Johnny Ibrahim, Teori \& Metodologi Penelitian Hukum Normatif, (Malang, Buyumedia Publishing, 2008)

M. Idris Ramulya, Hukum Pekawinan, Hukum Pewarisan, Hukum Kewarisan, Hukum Acara Peradilan Agama, (Jakarta: Sinar Grafika, 1995)

M. Thalib, Perkawinan Menurut Islam , (Surabaya: Al Ikhlas, 1993)

Mahkamah Agung RI, Buku II Pedoman Teknis Administrasi dan Teknis Peradilan Agama,(2008)

Peter Mahmud Marzuki,Penelitian Hukum, Kencana Prenada Media Group, Jakarta, 2011

RAKERNAS MARI, Makalah Pembanding Perdata Agama

Ronny Hanitijo Soemitro, Metodologi Penelitian Hukum dan jurimetri cetakan ketiga, ed revisi, Ghalia indonesia, 1998

Siti Musdah Mulia, Islam Menggugat Poligami, (Jakarta: PT. Gramedia Pustaka Utama, 2007)

Siti Musdah Mulia,Posisi Perempuan dalam Hukum Islam di Indonesia,(Jakarta: Kencana, 2008)

Soerjono soekanto, dan Sri Mamudji, Penelitian Hukum Normatif Suatu Tinjauan Singkat, Raja Grafindo Persada, Jakarta, 1995

Taufik Hamami, Mengenal Lebih Dekat Kedudukan dan Eksistensi Peradilan Agama Dalam Sistem Tata Hukum di Indonesia.

Yahya Harahap, Kedudukan dan Kewenangan dan Acara Peradilan Agama.

Undang-Undang Perkawinan No. 1 Tahun 1974

Kompilasi hukum Islam

Keputusan Ketua Mahkamah Agung RI Nomor : KMA/032/SK/IV/2006 tentang pemberlakuan "Buku II Pedoman Pelaksanaan Tugas dan Administrasi Peradilan Agama",

Departemen Agama Republik Indonesia, Al-Qur'an dan Terjemahnya 